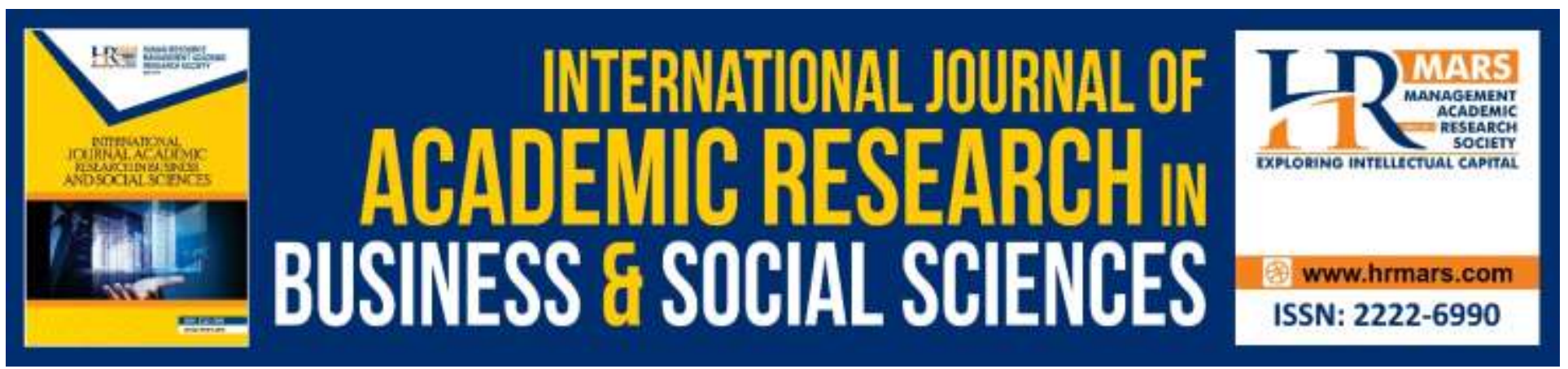

\title{
Effect of Treasury Single Account (TSA) on Corruption in the Nigerian Public Sector
}

John Ayoor Ivungu, Amos I. Ganyam, Alematu Agbo, Patience Ote Ola

To Link this Article: http://dx.doi.org/10.6007/IJARBSS/v10-i3/7021 DOI:10.6007/IJARBSS/v10-i3/7021

Received: 20 January 2020, Revised: 01 February 2020, Accepted: 22 February 2020

Published Online: 19 March 2020

In-Text Citation: (Ivungu et al., 2020)

To Cite this Article: Ivungu, J. A., Ganyam, A. I., Agbo, A., \& Ola, P. O. (2020). Effect of Treasury Single Account (TSA) on Corruption in the Nigerian Public Sector. International Journal of Academic Research in Business and Social Sciences, 10(3), 43-53.

Copyright: (C) 2020 The Author(s)

Published by Human Resource Management Academic Research Society (www.hrmars.com)

This article is published under the Creative Commons Attribution (CC BY 4.0) license. Anyone may reproduce, distribute, translate and create derivative works of this article (for both commercial and non-commercial purposes), subject to full attribution to the original publication and authors. The full terms of this license may be seen at: http://creativecommons.org/licences/by/4.0/legalcode

Vol. 10, No. 3, 2020, Pg. $43-53$

http://hrmars.com/index.php/pages/detail/IJARBSS

JOURNAL HOMEPAGE

Full Terms \& Conditions of access and use can be found at http://hrmars.com/index.php/pages/detail/publication-ethics 


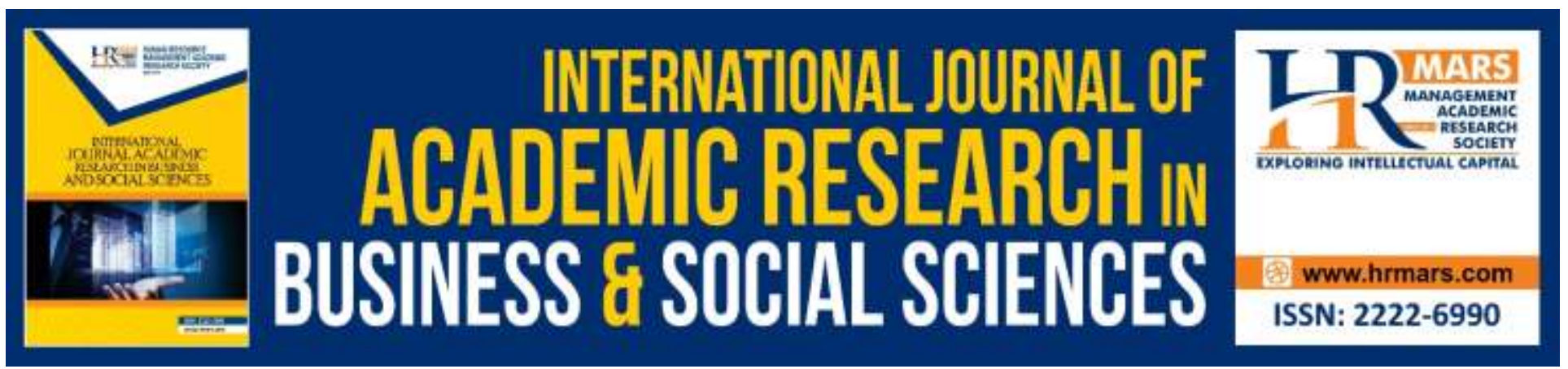

\title{
Effect of Treasury Single Account (TSA) on Corruption in the Nigerian Public Sector
}

\author{
John Ayoor Ivungu, Amos I. Ganyam, Alematu Agbo PhD, Patience \\ Ote Ola PhD \\ Department of Accounting, Faculty of Management Sciences, Benue State University, Makurdi - \\ Benue State, Nigeria \\ Email: ivungujohna@gmail.com, amosganyam@gmail.com, agboalematu@gmail.com, \\ olapatience@gmail.com
}

\begin{abstract}
This study examines the effect of treasury single account (TSA) on corruption in the Nigerian Public Sector. The extent to which TSA has affected the Corruption Perception Index (CPI) in Nigeria triggered this study. Data were obtained from Transparency International from 2012 to 2014 (before TSA adoption) and 2016-2018 (after TSA adoption), with 2015 as the base year. Data were analysed using descriptive statistics and paired samples t-test statistics. The study findings revealed that there is no significant difference in the mean of corruption perception index (CPI) before and after TSA adoption in Nigeria. The study concludes that TSA has not significantly reduced corruption in the Nigerian public sector. The study recommends that the Federal government should strengthen the judiciary, police, anti-graft agencies and the media in the country to tackle the issues of corruption and ensure transparency, probity and timeliness in handling corruption related cases.
\end{abstract}

Keywords: Treasury Single Account, Corruption, Public Sector, Corruption Perception Index

\section{Introduction}

Treasury single account (TSA), is one of the highly commendable strategies adopted by Nigerian President, Muhammadu Buhari to tackle incidences of public sector corruption, accountability, financial discipline and financial management in Nigeria. This policy came to lime light on the $9^{\text {th }}$ of August, 2015, when the president directed all the Ministries, Departments and Agencies (MDAs) to close down all accounts domiciled in deposit money banks in the country. The funds were to be transferred to the federation account, and deadline for total compliance was set on $15^{\text {th }}$ September, 2015.

Treasury single account is a public accounting system, under which all government revenue, receipts and income are collected into a single account, usually maintained by the country's Central Bank (Igbokwe-Ibeto, Nkomah, Osakede \& Kinge, 2016). TSA is a bank account or set of linked accounts through which the government transacts all its receipts and payments and is able to get a 
INTERNATIONAL JOURNAL OF ACADEMIC RESEARCH IN BUSINESS AND SOCIAL SCIENCES Vol. 10, No. 3, March, 2020, E-ISSN: 2222-6990 @ 2020 HRMARS

consolidated view of its position at any given time. With TSA government is able to centrally manage its receipts and payments that would have been formally remitted by the various MDAs from their different bank accounts.

Laudable among the motives behind the implementation of TSA was to curb corruption in the Nigerian public sector (Abdulrasheed, 2016). Corruption reduction was one of the promises of president Muhammadu Buhari during his presidential campaigns. As a strategy to fulfil his campaign promises, the TSA was approved. Corruption is not an innovate concept in public administration. Corruption has been a global experience as virtually all countries are faced with this menace (Osagioduwa, 2019). Before President Muhamadu Buhari came to power in 2015, there were series of corruption cases that ensued. Prominent among which was an alleged corruption case of Stella Oduah in 2013, an ex-aviation minister, who was accused of spending over 225 million on luxurious cars. Funds which were claimed to have been taken from the ministry's budget (Stober, 2019). Also, in 2013 Alhaji Maina, an ex-pension boss, was indicted for misappropriating billions of naira comprising of pension funds. He was accused of mopping up these funds from banks and depositing into his private account (Stober, 2019). Some of these corruption cases to a large extent would not have surfaced if TSA had existed.

However, despite the introduction of TSA in Nigeria, cases of corruption are still perceived in the Nigerian public sector. In 2016, the then Secretary to the Federal Government of Nigeria, Babachir Lawal was indicted in a $\$ 200$ million contract scandal for clearing intrusive plant species in internally displaced camps in Yobe State, a North Eastern state in Nigeria. Also, in 2018 the Director General of the National Emergency Management Agency (NEMA) in Nigeria, Mustapha Maihaja was indicted for mismanaging \#5.8 Billion Intervention Fund earmarked for interventions in the North Eastern part of the country (Stober 2019; Toromade 2018; Enofe Afiangbe and Agha 2017). Although most of these cases were investigated and actions were taken respectively, the fact that they came up in the first place indicates that the Nigerian public sector is still faced with accountability and corruption problems, and this has continued to affect the public perception on the effectiveness of government strategies to fight corruption in Nigeria. TSA as one of the prominent strategies to curb mismanagement of funds and corruption in the Nigerian public sector would have effectively mitigated against some of the issues of corruption that surfaced. Therefore, the fact that these cases surfaced has given rise to doubt as to the effectiveness of TSA in mitigating against corruption in Nigeria.

Studies abound that have examined the effect of TSA on corruption and public sector accountability in Nigeria. Osagioduwa (2019), Adeagbo and Oladeji (2019), Ganyam (2018), Akujuru and Enyioko (2017), Igbekoyi and Agbaje (2017) and Enofe, Afiangbe and Agha (2017), also examined this relationship. Although majority of these studies sugested TSA as an effective tool to mitigate against corruption and mismanagement of funds in the public sector, there is paucity of studies that have assessed the level of public sector corruption before and after TSA adoption in Nigeria. This is because, majority of extant literatures focused on the perception of public office holders on the effectiveness of TSA in curbing corruption in the Nigerian public sector. It is against this backdrop that this study intends to assess the effect of TSA on public sector corruption in Nigeria, by comparing the corruption perception index (CPI) before and after TSA adoption in Nigeria.

\section{Objective}

To ascertain whether there is a significant mean difference in corruption perception index (CPI) before and after TSA adoption in Nigeria. 
INTERNATIONAL JOURNAL OF ACADEMIC RESEARCH IN BUSINESS AND SOCIAL SCIENCES

Vol. 10, No. 3, March, 2020, E-ISSN: 2222-6990 @ 2020 HRMARS

\section{Hypothesis}

Ho: There is no significant difference in the mean corruption perception index (CPI) before and after TSA adoption in Nigeria.

\section{Review of Empirical Studies}

Effect of TSA on corruption and public sector financial accountability has gained significant research attention by several scholars. Osagioduwa (2019) investigated the effectiveness of the TSA Policy in combating corruption in Nigerian public sector. The study was carried out in 4 states and data were obtained through questionnaires administered to 264 respondents and analysed using descriptive statistics and percentages, Pearson Product Moment Correlation Coefficient (PPMCC) and the Mean. Findings revealed that the TSA policy is effective in combating corruption in the public sector of Nigeria and the TSA has resulted in more ineffectiveness in the administration of public sector organizations. TSA policy prevents proliferation of public funds by the MDAs and as such embezzlement of public funds by MDAs is likely to be impossible under TSA.

Adeagbo and Oladeji (2019) focused on appriasing the effectiveness of TSA as a tool for preventing leakages and enhancing the accountability of public funds in ministries, departments and agencies of government in Nigeria. Using survey research design, data were obtained from questionnaires administered on 120 staff from 7 MDAs and institutions. Descriptive statistics of percentages, mean and standard deviation were used to analyse the data, while regression was used for hypotheses testing. Findings revealed that TSA serves as a tool for preventing leakages and enhance proper accountability of public funds in Nigeria.

Ganyam (2018) ascertained the effect of TSA on financial accountability, corruption and financial discipline in the Nigerian public sector. Using survey research design, data were obtained from questionnaire issued to 95 senior and management staff from 5 MDAs in Benue State, Nigeria. The data were analysed using the ANOVA test at $5 \%$ level of significance. Findings from the study revealed that TSA significantly promotes accountability of public funds in Nigeria, reduces the level of corruption in the Nigerian public sector and enhances financial discipline in the Nigerian public sector.

Akujuru and Enyioko (2017) ascertained the effects of treasury single account policy on corruption in Nigeria from 2011 to 2017 . The study adopted a cross sectional survey design and used questionnaire to generate its data from 377 staff from the federal ministries, departments and agencies (MDAs) in Rivers State. The data were analysed through the use of descriptive statistics. Findings from the study revealed that the TSA policy will pave the way for the timely payment and capturing of all revenues going into the government treasury, without the intermediation of multiple banking arrangements. Also, the policy will enable the government at the center to know its cash position at any given time without hindrances.

Igbekoyi and Agbaje (2017) analysed the implication of TSA adoption on accountability and transparency in the Nigerian public sector. Data were obtained from 10 MDAs involved in revenue generation which were purposively sampled. Data were anlsyed using ANOVA and regression analysis. They found that TSA has significant and positive impact on financial leakages, transparency and curbing of financial misappropriation. 
INTERNATIONAL JOURNAL OF ACADEMIC RESEARCH IN BUSINESS AND SOCIAL SCIENCES Vol. 10, No. 3, March, 2020, E-ISSN: 2222-6990 @ 2020 HRMARS

Nwaorgu and Ezenwaka (2017) investigated the effect of TSA on accountability in the Nigerian Public Sector. Data relating to the study were obtained from questionnaires administered on 250 respondents randomly selected from the Accounts departments of four federal health tertiary institutions in Nigeria. Data were analysed using descriptive statistics and regression. Findings disclosed that adaptation of a treasury single account (TSA) in the Nigerian Public Sector is capable of plugging financial loopholes, promoting transparency and accountability in federal health tertiary institutions in South-East Nigeria.

Enofe, Afiangbe and Agha (2017) investigated financial management reforms and corruption in Nigerian public sector. The study adopted a survey research design, where data were obtained from 90 respondents (staff from federal, state and local government MDAs). The study employed ordinary least square (OLS), technique. Findings revealed that the introduction and application of TSA will not reduce corruption in the Nigerian public sector.

Adebisi and Okike (2016) studied the adoption of the treasury single account (TSA) and its effect on revenue leakages of Nigerian states. Data relating to the study were obtained from questionnaires. Data were analysed using regression analysis. The results revealed that the TSA adoption is an effective tool for curbing revenue leakage in Nigerian states.

Oti, Igbeng and Obim (2016) analysed the policy impact of TSA in Nigeria. Using a survey and exploratory research design, data were obtained from questionnaires administered to individuals and institutions. Data were anlysed using frequency, percentages and mean of responses issued by respondents. Findings revealed that TSA policy has brought about transperency and fiscal management in the public sector.

Yusuf and Mohammed (2016) ascertained the effect of TSA policy on public financial management in Nigeria and its benefits if properly implemented. Primary and secondary data were employed by the researchers. Data were obtained from respondents from MDAs in Damaturu, Yobe State and analysed using ANOVA techniques. The result of the study revealed that, proper implementation of TSA by all stakeholders will help tremendously in reducing corruption, mismanagement of Public funds, block leakages and other financial irregularities in states and the country at large. Again, the researchers conducted a similar study in Bauchi state using 75 respondents from MDAs in the state in 2016. Data were analysed using Pearson Correlation techniques. Findings revealed that adoption of TSA is capable of plugging financial loopholes, promoting transparency and accountability in the public Financial System.

From the above, it is evident that majority of the researchers made use of questionnaires in analysing the effect of TSA on corruption. This study therefore attempts to contribute to existing literature on the subject by using secondary sources of data to analyse how Nigeria has fared in terms of reducing corruption before and after the TSA implementation.

\section{Methodology}

This study adopts a descriptive form of ex-post facto research design in examining the effect of TSA on corruption in Nigeria. This research design is ideal for the study because it helps in ascertaining the effect of past factors on present happening or event. It is also ideal for studies involving secondary sources of data (Akpa, 2011). Data relating to the study were obtained from Transparency International (2018) from 2012 to 2014 (before TSA adoption) and 2016-2018 (after TSA adoption). 2015, which was when TSA became officially effective served as the base year. Corruption perception 
INTERNATIONAL JOURNAL OF ACADEMIC RESEARCH IN BUSINESS AND SOCIAL SCIENCES Vol. 10, No. 3, March, 2020, E-ISSN: 2222-6990 C 2020 HRMARS

index (CPI), which is a score that relates to perceptions of the degree of corruption as seen by business people and country analyts served as the main variable of the study. According to Knoema (2018) it is usually conducted by Transparency International yearly and ranges between 100 (highly clean) and 0 (highly corrupt) .

The study uses descriptive statistics to compute a summary statistic for the study variable. This is important because it summarizes and enhances the understanding of data collected for analysis in a study. The study also employs paired sample t-test statistics to test the hypotheses that "there is no significant difference in the mean corruption perception index (CPI) before and after TSA adoption in Nigeria". The nature of this research, which hinges on comparability of the pre and post TSA periods, makes the paired sampled t-test statistics preferable (Akpa, 2011). Data are analysed using the Statistics/Data Analysis software (STATA), version 16.

\section{Results}

Two sets of data were collected for the study before and after TSA adoption. This is presented in Table 1.

Table 1: Descriptive Statistics

\begin{tabular}{llllll}
\hline Variable & Obs & Mean & Std. Dev. & Min & Max \\
\hline PRETSA(CPI) & 3 & 26.33 & 1.16 & 25 & 27 \\
POSTTSA(CPI) & 3 & 27.33 & 0.58 & 27 & 28 \\
\hline
\end{tabular}

\section{Source: STATA Output, Version 16}

Table 1 presents the number of observations, mean, standard deviation, minimum and maximum values of the study variable. The number of observations reveals a value of ' 3 ', indicating that PRETSA(CPI) and POSTTSA(CPI) were obtained for 3 years each (2014-2012 and 2018-2016). PRETSA(CPI) also revealed a mean and standard deviation of 26.33 and 1.16 respectively. This indicates that the average consumer perception index score of Nigeria during the period before TSA adoption stood at about $26 \%$, with variations in the number amounting to 1.15 . This implies that during the period, the average degree of corruption as perceived by business people and country analyst was $26 \%$. During the PRETSA(CPI) periods also, the minimum CPI stood at $25 \%$ while the maximum stood at 27\%. POSTTSA(CPI) as presented in Table 1 also revealed a mean, standard deviation, minimum and maximum values of $27.33,0.58,27$ and 28 respectively. This indicates that during the post TSA periods, CPI averagely stood at $27 \%$ with fluctuations amounting to 0.58 . This indicates that during the period, the average degree of corruption as perceived by business people and country analyst was $27 \%$. The minimum CPI during the period stood at $27 \%$ while the maximum stood at $28 \%$. 
INTERNATIONAL JOURNAL OF ACADEMIC RESEARCH IN BUSINESS AND SOCIAL SCIENCES

Vol. 10, No. 3, March, 2020, E-ISSN: 2222-6990 C 2020 HRMARS

\section{Figure 1: Graphical representation of CPI during the study period}

Nigerian CPI 2012-2018

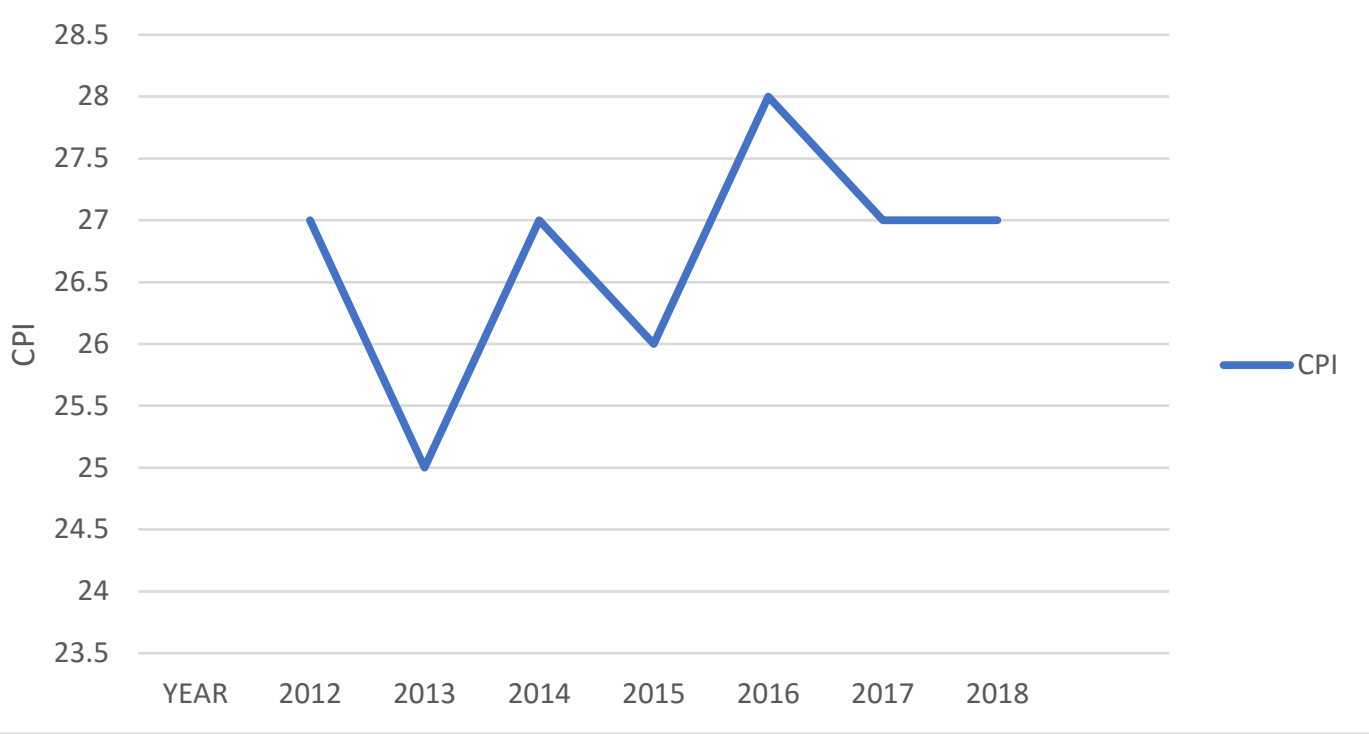

From Figure 1, corruption perception index (CPI) in Nigeria reveals an undulating movement pattern from 2012 to 2018. It drops steeply in 2013 from 27\% to 25\% and climbed immediately in 2014 with a score of $27 \%$. In 2015, CPI dropped to $26 \%$ and climbed higher in 2016 with about $28 \%$. This was the highest recorded during the study period. However, it finally drops in 2018 to $27 \%$.

Table 2: Paired T-test Results

\begin{tabular}{lllllll}
\hline Variable & Obs & Mean & Std. Err. & Std. Dev. & [95\% Conf. & Interval] \\
\hline pretsa $\sim \mathrm{i}$ & 3 & 26.33 & 0.67 & 1.16 & 23.47 & 29.20 \\
posttsa $\sim \mathrm{i}$ & 3 & 27.33 & 0.33 & 0.58 & 25.90 & 28.77 \\
Diff & 3 & -1 & 0.58 & 1 & -3.48 & 1.48 \\
\hline
\end{tabular}

$\mathrm{t}=-1.7321$

$\mathrm{df}=2$

$p$-value $=0.2254$

\section{Source: STATA Output, Version 16}

Results from Table 2 reveals a mean difference of -1 , a standard error of 0.58 and standard deviation of 1. This indicates an increase in corruption perception index during the period after TSA adoption. The P-value of 0.23 indicates that, the increase in corruption perception index during the period after TSA adoption is not significant at $5 \%$ level of significance. This implies that although corruption is perceived to have increased during the TSA period, the increase is not significant.

\section{Test of Hypothesis}

$\mathrm{Ho}_{1}$ : There is no significant difference in the mean of corruption perception index (CPI) before and after TSA adoption in Nigeria. 
INTERNATIONAL JOURNAL OF ACADEMIC RESEARCH IN BUSINESS AND SOCIAL SCIENCES

Vol. 10, No. 3, March, 2020, E-ISSN: 2222-6990 @ 2020 HRMARS

Given that the t statistics as presented in Table 2 reveals a value of -1.73 and a p-value of 0.23 , the null hypothesis that there is no significant difference in the mean of corruption perception index (CPI) before and after TSA adoption in Nigeria is accepted.

\section{Discussion}

Findings from the study revealed that there is no significant difference in the mean of corruption perception index (CPI) before and after TSA adoption in Nigeria. The current Nigerian government may have invested sufficiently in strategies to mitigate corruption in the Nigerian public sector. However, the study's findings suggest that the public still perceive corruption to be rather increasing in Nigeria. This may be attributed to the unenthusiastic manner in which some of the corruption charges on public office holders are handled. In the case of the then secretary to the Federal government in 2016 for instance, decisive actions that led to his removal were only taken after the Vice president's committee reconstituted by the president to look into the matter made their submission. The president had earlier rejected the verdict of the senate committee that investigated the issue on the basis of fair hearing (Toromade, 2018). This kind of action is capable of eroding the public confidence in the government in tackling incidences of corruption as depicted by the Nigerian corruption perception index.

The introduction of TSA would have no doubt curbed some of these corruption cases at inception. The case of the NEMA boss indicted for mismanaging funds for interventions in the North Eastern part of Nigeria might not have surfaced in the first place if TSA was properly complied upon. This then suggests that not all government MDAs are fully TSA compliant. This agrees with the submission of Agabi (2019) who stated that a significant number out of the 900 MDAs in Nigeria have either complied or partially implementing TSA in flagrant violation of the presidential directive. Although the findings of this study agrees with the findings of Enofe, Afiangbe and Agha (2017), who found that the introduction and application of TSA will not reduce corruption in the Nigerian public sector, it however contradicts the findings of Osagioduwa (2019), Ganyam (2018), Akujuru and Enyioko (2017), Igbekoyi and Agbaje (2017) and Nwaorgu and Ezenwaka (2017).

\section{Conclusion and Recommendations}

Corruption, like a cankerworm has eaten deep into our society today. Government on its own part has never relented in its mandate to fight corruption. TSA was introduced with the foresights to mitigate corruption in the Nigerian public sector. However, in line with the study findings, it is concluded that TSA has not significantly reduced corruption in the Nigerian public sector. To this end, we recommend that, TSA adoption alone may not be sufficient to curb corruption in the Nigerian public sector hence the need for the judiciary, police, anti-graft agencies and the media in the country be strengthened to tackle the issues of corruption and ensure transparency, probity and timeliness in handling corruption related cases. This will caution the general public and public office holders on corrupt practices.

\section{References}

Abdulrasheed, B. (2016). Treasury Single Account (TSA), as a tool for Managing Public Finances in Nigeria. A seminar presented at the department of Accounting, Faculty of Management Sciences, Usmanu Danfodiyo University Sokoto. Sokoto: Usmanu Danfodiyo University, Sokoto. 
INTERNATIONAL JOURNAL OF ACADEMIC RESEARCH IN BUSINESS AND SOCIAL SCIENCES Vol. 10, No. 3, March, 2020, E-ISSN: 2222-6990 @ 2020 HRMARS

Adeagbo, K., \& Oladeji, W. (2019). Treasury Single Account: A tool for Preventing Leakages and Enhancing Accountability of Public Funds in Nigeria. International Journal of Social Sciences and Management Review, 2(4), 69-83.

Adebisi, J., \& Okike, B. (2016). The Adoption of the Treasury Single Account (TSA) and Its Effect on Revenue Leakages of Nigerian States. American Research Journal of Business and Management, 2, 1-10.

Akpa, A. (2011). Knowledge Creation Process: Concepts and Application in Social Research. Makurdi: Aboki Publisher.

Akujuru, C., \& Enyioko, N. (2017). Effects of Treasury Single Account Policy on Corruption in Nigeria. SSRN, 1-23.

Alzgool, M. (2019). Nexus between Green HRM and Green Management towards Fostering Green Values. Management Science Letters, 9(12), 2073-2082.

Enofe, A., Afiangbe, S., \& Agha, D. (2017). Financial Management Reforms and Corruption in Nigeria Public Sector. International Journal of Advanced Academic Research / Social \& Management Sciences, 3(7), 1-22.

Ganyam, A. (2018). Effect of Treasury Single Account (TSA) on Financial Accountability, Corruption and Financial Discipline in the Nigerian Public Sector. Retrieved from ResearchGate: https://www.researchgate.net/publication/326986103_Effect_of_Treasury_Single_Account _TSA_on_Financial_Accountability_Corruption_and_Financial_Discipline_in_the_Nigerian_P ublic_Sector

Khalid, N., Islam, D. M. Z., \& Ahmed, M. R. M. (2019). Sentrepreneurial Training and Organizational Performance: Implications for Future. Humanities \& Social Sciences Reviews, 7(2), 590-593.

Igbekoyi, O., \& Agbaje, W. (2017). An assessment of the implication of Treasury Single Account. European Journal of Accounting Auditing and Finance Research, 5(8), 33-49.

Igbokwe-lbeto, C., Nkomah, B., Osakede, K., \& Kinge, R. (2016). Treasury Single Account Transparency and Accountability in Public Finance Management in Nigeria: The Journey So Far. Africa's Public Service Delivery \& Performance Review, 342-359.

Knoema. (2018). Corruption Perception Index. Retrieved January 21, 2020, from Knoema: https://knoema.com/atlas/Nigeria/Corruption-perceptions-index?mode=amp

Nwaorgu, I., \& Ezenwaka, F. (2017). Treasury Single Accounting (TSA) and Public Sector Accountability in Nigeria. Journal of Economics, Management and Trade, 19(4), 1-8.

Osagioduwa, L. (2019). Treasury Single Account Effectiveness on Corruption Control and Public Organizations Efficient Administration in Nigeria. International Journal of Management Studies and Social Science Research, 1(5), 1-19.

Oti, P., Igbeng, E., \& Obim, E. (2016). Appraisal of Policy Impact of Treasury Single Account in Nigeria. Research Journal of Finance and Accounting, 7(20), 45-52.

Stober, E. (2019). Nigeria's Corruption Score Card. Management Dynamics in the Knowledge Economy, 7(2), 165-182.

Toromade, S. (2018). Pulse List 2018: Top 5 corruption stories in Nigeria. Retrieved 1 20, 2019, from Palse Nigeria: https://www.pulse.ng/news/local/pulse-list-2018-top-5-corruption-stories-innigeria/5b98jm9

Transparency International. (2018). Corruption Perception Index. Retrieved from Transparency International: https://www.transparency.org/files/content/pages/2018_CPI_FullResults.zip

Yusuf, A., \& Mohammed, B. (2016). Effects of Treasury Single Account on Public Finance Management in Nigeria. Research Journal of Finance and Accounting, 7(6), 164-170. 
INTERNATIONAL JOURNAL OF ACADEMIC RESEARCH IN BUSINESS AND SOCIAL SCIENCES

Vol. 10, No. 3, March, 2020, E-ISSN: 2222-6990 @ 2020 HRMARS

Yusuf, A., \& Mohammed, S. (2016). Treasury Single Account (TSA) as an effective Instrument of Financial Prudence and Management in Nigeria: Prospects and Problems. Nigerian Journal of Management Technology and Development, 7(2), 200-207. 
INTERNATIONAL JOURNAL OF ACADEMIC RESEARCH IN BUSINESS AND SOCIAL SCIENCES

Vol. 10, No. 3, March, 2020, E-ISSN: 2222-6990 @ 2020 HRMARS

Corruption Perception Index (CPI) of Sub-Saharan African Countries from 2012-2018

\begin{tabular}{|c|c|c|c|c|c|c|c|c|}
\hline$S / N$ & Country & 2018 & 2017 & 2016 & 2015 & 2014 & 2013 & 2012 \\
\hline 1 & Seychelles & 66 & 60 & & 55 & 55 & 54 & 52 \\
\hline 2 & Botswana & 61 & 61 & 60 & 63 & 63 & 64 & 65 \\
\hline 3 & Cabo Verde & 57 & 55 & 59 & 55 & 57 & 58 & 60 \\
\hline 4 & Rwanda & 56 & 55 & 54 & 54 & 49 & 53 & 53 \\
\hline 5 & Namibia & 53 & 51 & 52 & 53 & 49 & 48 & 48 \\
\hline 6 & Mauritius & 51 & 50 & 54 & 53 & 54 & 52 & 57 \\
\hline 7 & Sao Tome and Principe & 46 & 46 & 46 & 42 & 42 & 42 & 42 \\
\hline 8 & Senegal & 45 & 45 & 45 & 44 & 43 & 41 & 36 \\
\hline 9 & South Africa & 43 & 43 & 45 & 44 & 44 & 42 & 43 \\
\hline 10 & Burkina Faso & 41 & 42 & 42 & 38 & 38 & 38 & 38 \\
\hline 11 & Ghana & 41 & 40 & 43 & 47 & 48 & 46 & 45 \\
\hline 12 & Lesotho & 41 & 42 & 39 & 44 & 49 & 49 & 45 \\
\hline 13 & Benin & 40 & 39 & 36 & 37 & 39 & 36 & 36 \\
\hline 14 & Swaziland & 38 & 39 & & & 43 & 39 & 37 \\
\hline 15 & Gambia & 37 & 30 & 26 & 28 & 29 & 28 & 34 \\
\hline 16 & Tanzania & 36 & 36 & 32 & 30 & 31 & 33 & 35 \\
\hline 17 & Cote d'Ivoire & 35 & 36 & 34 & 32 & 32 & 27 & 29 \\
\hline 18 & Zambia & 35 & 37 & 38 & 38 & 38 & 38 & 37 \\
\hline 19 & Ethiopia & 34 & 35 & 34 & 33 & 33 & 33 & 33 \\
\hline 20 & Niger & 34 & 33 & 35 & 34 & 35 & 34 & 33 \\
\hline 21 & Liberia & 32 & 31 & 37 & 37 & 37 & 38 & 41 \\
\hline 22 & Malawi & 32 & 31 & 31 & 31 & 33 & 37 & 37 \\
\hline 23 & Mali & 32 & 31 & 32 & 35 & 32 & 28 & 34 \\
\hline 24 & Djibouti & 31 & 31 & 30 & 34 & 34 & 36 & 36 \\
\hline 25 & Gabon & 31 & 32 & 35 & 34 & 37 & 34 & 35 \\
\hline 26 & Sierra Leone & 30 & 30 & 30 & 29 & 31 & 30 & 31 \\
\hline 27 & Togo & 30 & 32 & 32 & 32 & 29 & 29 & 30 \\
\hline 28 & Guinea & 28 & 27 & 27 & 25 & 25 & 24 & 24 \\
\hline 29 & Comoros & 27 & 27 & 24 & 26 & 26 & 28 & 28 \\
\hline 30 & Kenya & 27 & 28 & 26 & 25 & 25 & 27 & 27 \\
\hline 31 & Mauritania & 27 & 28 & 27 & 31 & 30 & 30 & 31 \\
\hline 32 & Nigeria & 27 & 27 & 28 & 26 & 27 & 25 & 27 \\
\hline 33 & Central African Republic & 26 & 23 & 20 & 24 & 24 & 25 & 26 \\
\hline 34 & Uganda & 26 & 26 & 25 & 25 & 26 & 26 & 29 \\
\hline 35 & Cameroon & 25 & 25 & 26 & 27 & 27 & 25 & 26 \\
\hline 36 & Madagascar & 25 & 24 & 26 & 28 & 28 & 28 & 32 \\
\hline 37 & Eritrea & 24 & 20 & 18 & 18 & 18 & 20 & 25 \\
\hline 38 & Mozambique & 23 & 25 & 27 & 31 & 31 & 30 & 31 \\
\hline 39 & Zimbabwe & 22 & 22 & 22 & 21 & 21 & 21 & 20 \\
\hline 40 & Democratic Republic of the Congo & 20 & 21 & 21 & 22 & 22 & 22 & 21 \\
\hline 41 & Angola & 19 & 19 & 18 & 15 & 19 & 23 & 22 \\
\hline 42 & Chad & 19 & 20 & 20 & 22 & 22 & 19 & 19 \\
\hline 43 & Congo & 19 & 21 & 20 & 23 & 23 & 22 & 26 \\
\hline 44 & Burundi & 17 & 22 & 20 & 21 & 20 & 21 & 19 \\
\hline 45 & Equatorial Guinea & 16 & 17 & & & & 19 & 20 \\
\hline 46 & Guinea Bissau & 16 & 17 & 16 & 17 & 19 & 19 & 25 \\
\hline 47 & Sudan & 16 & 16 & 14 & 12 & 11 & 11 & 13 \\
\hline 48 & South Sudan & 13 & 12 & 11 & 15 & 15 & 14 & \\
\hline 49 & Somalia & 10 & 9 & 10 & 8 & 8 & 8 & 8 \\
\hline
\end{tabular}

Source: Transparency International (2018) 